\title{
Business Model Innovation and the First Steps of Digitalization in the Case of Symphony Orchestras
}

\author{
BORBÁLA SZEDMÁK* \\ *Corvinus University of Budapest, Institute for the Development of Enterprises; \\ borbala.szedmak@uni-corvinus.hu
}

DOI: $10.14267 / 978-963-503-867-1 \_15$

\begin{abstract}
The study highlights the importance of orchestras being able to respond to the changing needs of consumers and adapt to changes in the world. Such a change is, for example, the current coronavirus epidemic, which poses especially great difficulties for organizations of the cultural sector that deal with performing arts, as concerts and performances - providing the basis of their operation - have become impossible. In order to gain "immunity" to the virus, business model innovation and exploiting opportunities offered by digitalization are essential. Furthermore, similar cases can occur at any time for which orchestras have to be prepared. As a result, orchestras (and in a broader sense all kinds of organizations) need to fundamentally rethink their business models. After conducting secondary research and interviews with 10 symphony orchestra managers and 10 symphony orchestra musicians, I have identified some novel aspirations, attempts and projects selected from international and Hungarian symphonic orchestral life to provide excellent examples of how the business model can be redefined and how the expectations of the $21^{\text {st }}$-century audience can be met. These examples show that there are orchestras which have understood that responding to the changing demands of consumers and utilizing the opportunities given by technology is essential, although it is still a question of how many more "coronavirus waves" are needed to make it clear for all orchestras that fundamental changes are necessary to preserve a market-leading position or become a market leader.
\end{abstract}

Keywords: business model, symphony orchestra, digitalization

Funding: The present publication is the outcome of the project „From Talent to Young Researcher project aimed at activities supporting the research career model in higher education," identifier EFOP-3.6.3-VEKOP-16-2017-00007 co-supported by the European Union, Hungary, and the European Social Fund. 


\section{Introduction}

Regardless of the industry, in today's ever-changing world no business model is forever: it has to be tailored to the current needs, market, social and environmental conditions in order to prosper in the future as well. The importance of business model innovation is also highlighted by the current coronavirus situation: only those organizations can survive or even be the winner of the pandemic which can renew their operation. The situation both gives an opportunity to the organizations and forces them to change and fundamentally rethink their operation. The pandemic causes an extremely difficult situation for symphony orchestras, as they have to cancel their performances and redefine how to reach their audience. Orchestras which can react quickly - or can react at all - to the new circumstances will be able to survive this period and may gain competitive advantage. In the case of those which cannot tailor their operation to the present situation - and in a broader sense, to the changing needs of the $21^{\text {st }}$ century -, survival is questionable.

This study aims to identify novel aspirations and innovative projects of symphony orchestras compared to the 'traditional' orchestra model which exclusively focuses on the preservation of classical music in the physical space. I presume that these novel attempts change significantly one or more elements of the orchestras' business models and exploit the opportunities offered by digitalization.

\section{Theoretical background}

Although the first appearance of the term 'business model' dates back to the 1950s, the concept of business model became popular only around the mid-1990s, with the advent of the internet and information technologies (Zott et al., 2011; Downs \& Velamuri, 2018). Though Porter (2001) interpreted business modeling as a useless concept, several studies have pointed out its practical benefits. Nowadays, in a rapidly changing world, fast responsiveness to challenges, adaptability to changes, and the ability to dynamically renew the operation of an organization are gaining even more importance. It provides an opportunity for fast, focused, real exploration and learning with little use of resources (Horváth et al., 2018).

Business model represents the operational logic of the organization - in other words, the system of "business" ("how the organization creates, delivers and captures value," Osterwalder \& Pigneur, 2010, p. 14.) - and focuses on the way that value is created. According to these three dimensions, the authors have developed a business model canvas with nine building blocks (BMC: Business Model Canvas, see Table 1). 
Business modeling tools are not only suitable for reviewing the operation of for-profit companies. In the case of non-profit organizations, serving social goals as well, value creation has a dual focus: in addition to economic value, they also have to create social value (Weerawardena et al., 2019). Although these organizations do not focus on maximizing profits, they cannot ignore economic considerations. A business model is only viable, and an organization can only pursue its social or cultural goals if it generates more revenue than costs.

Digital transformation is fundamentally changing how organizations operate and deliver value to customers. The advancement of technology inevitably affects competition and strategies (Mészáros, 2020). According to the list of Forbes (2020), the most valuable companies have platform business models (e.g., Apple, Google, Microsoft, Amazon, Facebook). In recent decades, platforms have become the new management paradigm and have been studied widely (Csontos \& Szabó, 2018), for example in the case of (smart) cities (Csukás \& Szabó, 2019) or in connection with industry 4.0 (Szabó et al. 2019). Platforms are often considered 'network orchestrators' (Libert et al. 2014) and can facilitate value creation by providing opportunities for content producers ('creators') to present their offers to other segments (Van Alstyne, 2016, Gawer \& Cusumano, 2014, Eisenmann et al., 2011). It is important to emphasize the significance of ICT in knowledge transfer and on the job learning (Hortoványi \& Ferincz, 2015) in connection with platform business models as well: it can be an internal development barrier if some employees are unable to use the platform.

In a rapidly changing world, no business model is forever; it needs to be continuously improved in order to survive and operate successfully. Thus, in the case of symphony orchestras, it is not enough to rely on the existing repertoire and follow traditional models. One of the biggest challenges for symphony orchestras is the question of the next generation of concertgoers (Bibu et al., 2018). Concerts can only reach a narrow section of the population - as opposed to cinemas or theaters which are much more popular. According to Alexander (2015), art that no one wants to pay for cannot survive. Orchestras must therefore strive to reach and address a wider range of consumers. Without innovatively rethinking their operation and "services", orchestras will find it difficult to win against other segments of the entertainment industry (e.g., pop music concerts, cinemas) in the competition for people's leisure time (Radbourne \& Arthurs 2007). Business model innovation is therefore needed to ensure the prosperity of orchestras in the 21st century. Business model innovation means that there is a significant change in one or more elements of the organization's business model (Horváth et al. 2018). In order to successfully innovate the business model, entrepreneurial managers are needed who can drive economic growth (Hortoványi, 2012) and can "develop and play an 
altogether different game" instead of "playing the game better than the competitors" (Markides, 1997, p. 9.).

By redefining the business model and the standards of an industry, the organization can achieve a more customer-oriented approach and address potential future customers as well. Compared to the traditional orchestral operating model, such innovative solutions can be recognized both on the international scene and in Hungary. This study aims to give an overview of these novel aspirations.

\section{Methodology}

In order to answer my research question (What kind of novel aspirations and innovative projects can be identified in the case of symphony orchestras?), I have conducted primary and secondary research as well. Figure 1 summarizes the main steps of my research.

Figure 2: Methodology

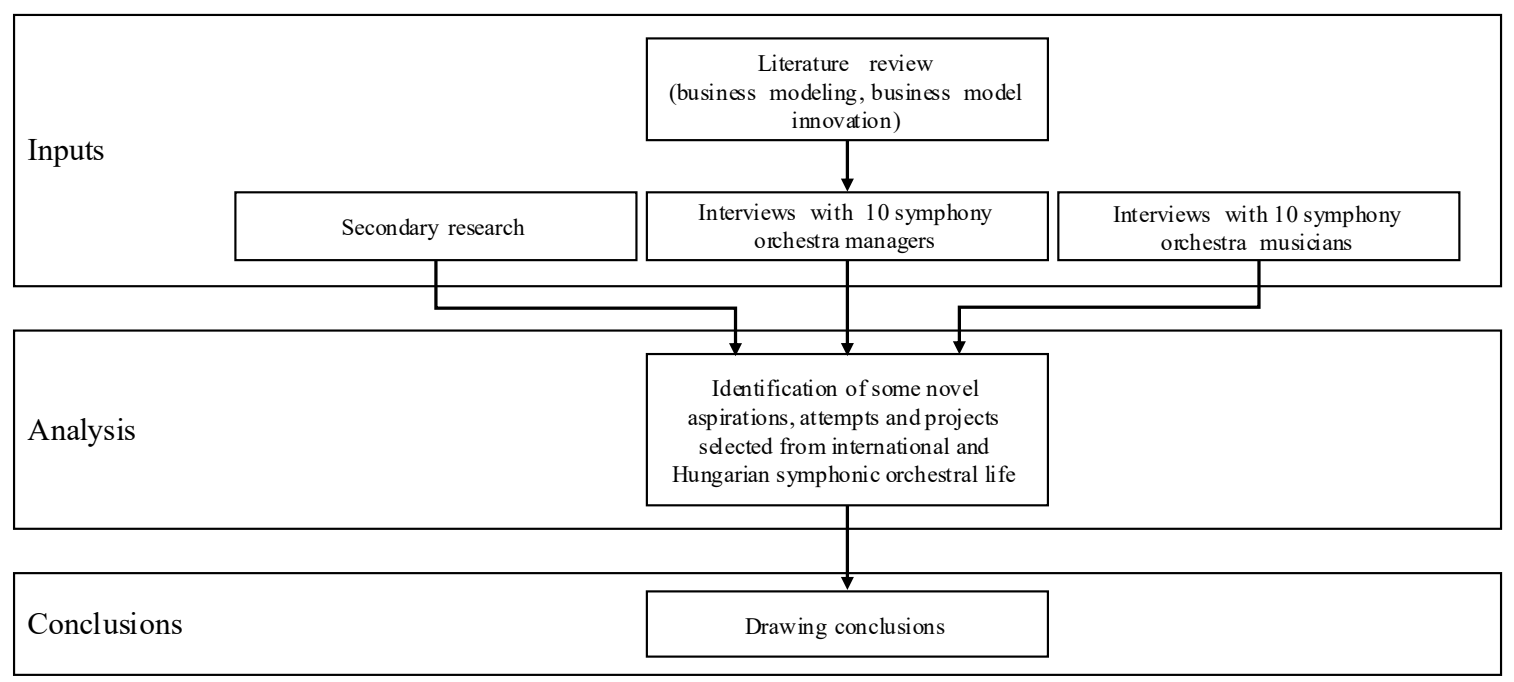

Source: own editing

In the frames of my primary research, I have conducted interviews with symphony orchestra managers and musicians. My main questions were focusing on the challenges of orchestras, the effects of COVID-19 on the symphonic orchestral life and the novel projects and ways how they are trying to reach more people - especially the youth. I was also interested in their opinions about the international scene, however, in the case of foreign orchestras, my research mainly relies on existing documents, articles. 
I have worked with semi-structured interviews: I have prepared a guideline in advance, however, during the interview I have deviated from it if it was needed, in order to go into more details on some topics. This interview technique has given me a fairly high degree of freedom and as a result - by following the recommendations of Agee (2009) - it has allowed me to identify new, unexpected, previously unexplained phenomenon by not sticking to a pre-designed set of questions. The interviews lasted 60-90 minutes, respectively. For recruiting interviewees, I have used snowball sampling (Naderifar, Goli \& Ghaljaie, 2017). I have reached the theoretical saturation point after 10 interviews both in the case of managers and musicians: new topics have no longer emerged (Constantinou et al., 2017).

Based on the interviews and the secondary research, I have identified some novel aspirations and innovative attempts which are detailed in the following section.

\section{Results}

\section{Innovative repertoire - addressing and involving new audiences}

We can often hear about the problem of the aging audience of classical music (Váradi, 2010, Figaro, 2013). In order to have a music-lover core audience in the future as well, great attention must be paid to reaching out to new segments, especially younger people, and expanding the target market. Having recognized that today's consumers, especially the younger ones, typically appreciate creative, innovative productions, many orchestras have come up with innovative repertoires and productions: they come up with a novel concept, look for unusual concert venues, or integrate different genres and branches of art into their programs (see e.g., the Cincinnati Symphonic Orchestra, the Brooklyn Philharmonic, the Dohnányi Orchestra of Budafok or the Danubia Orchestra of Óbuda).

Reaching a new audience is not only possible with an innovative repertoire. Many orchestras try to engage a wider range of consumers with unconventional concerts that adapt to the rhythm of young people's lives by breaking the conventions and leaving the formalities (see e.g., the Midnight Music concert series of the Budapest Festival Orchestra, the "Spicy Classics" series of the South Netherlands Philharmonic or the "Night/Light" concerts of the above-mentioned Cincinnati Symphony Orchestra). 


\section{Online streaming through platforms}

Digitization opens up new ways for the orchestras to rethink their value proposition and also to reach and address audiences in an unusual way. Nowadays, "digital thinking" is essential in the field of cultural management as well (Hunt, 2019). Live concert streaming is no longer a novelty; however, the Berlin Philharmonic's Digital Concert Hall project was the first initiative that used social media to broaden the audience globally by making the orchestra's concert recordings available to consumers around the world via the Internet (Digital Concert Hall, 2019). Thus, the audience can access the orchestra's recordings or even live concerts anytime, anywhere. Nowadays, almost all orchestras both international and Hungarian - make available previous concert recordings and live performances by online streaming, which is currently gaining even more importance in the pandemic situation.

According to the research of the Association of Hungarian Symphony Orchestras (2020), Hungarian orchestras have previously used the Internet to share their productions, however, no content has been created specifically for the online space. In 2020, as a result of the pandemic, it has fundamentally changed: the vast majority of orchestras have started to use social media to stay in touch with their audiences, and due to the closure of concert halls, online, live concert streaming has become a popular way to perform. Streaming typically serves a dual purpose: on the one hand, it helps to keep in touch with the audience, and on the other hand, it can also generate income, if the orchestra makes its production available in exchange for a "ticket". For online streaming, most orchestras use YouTube Live, Facebook Live, or Instagram Live which are widely known and easily accessible platforms. Although it is worth examining some further options which are more professional and give better opportunities for the monetization of the productions (e.g., Dacast used by the Royal Academy of Music or Brightcove used by the Metropolitan Opera, the Sydney Symphony Orchestra, and the San Francisco Opera). Some of these platforms are specialized for music (e.g., Stageit) and besides ensuring the conditions of streaming, they also market the performer and their show (Corton, 2020). 


\section{LOLA - a software to decrease latency and a platform to connect musicians}

Nowadays, there are many technologies and applications which make it possible to teach and play music online (e.g., Skype, Messenger, Viber, Teams, Google Meet). These are widely known, easily accessible, and free solutions that do not require any special tools. In many cases, however, latency and the poor quality of sound cause serious problems. In contrast, LOLA (low latency AV streaming system) can reduce latency to less than 30 milliseconds and as a result, it is suitable for distance musical interactions, even in the case of a very 'tempo sensitive' repertoire where timing is a critical factor (Drioli et al., 2013). Thanks to LOLA, several successful productions have taken place in recent years, even if the performers were thousands of kilometers apart (LOLA, 2021). The ease of use of the software is proven by the fact that concerts were successful even in cases when the musicians started to get to know each other and the software just one day before the concert (without any special training).

\section{Interactive productions with gamification}

As previously mentioned, one of the main problems for symphony orchestras is that they can hardly address the youth. The Australian Discovery Orchestra has responded to the challenge with an excellent idea: as part of its digital strategy, it has turned its previous recordings into "virtual experiences". The audience can listen to the piece by playing a video game: they have to solve various challenges and complete tasks in order to earn points and ,keys” which unlock the next part of the piece (Grasmayer, 2017). In another video game, the orchestra focuses on music education in a similar way, by using a virtual environment, short videos, and audio materials (ADO, 2021).

\section{Effective workflows enhanced by virtual reality}

The cooperation of two Finnish VR pioneers (Zoan and Varjo) and the Finnish National Opera and Ballet (FNOB) points out that new technologies have a raison d'être in the field of culture as well, by contributing to more efficient workflows. In the frames of the collaboration, FNOB has the chance to pre-visualize the upcoming productions without much investment. As a result, FNOB can save stage time and make the processes more effective (Teivainen, 2020). 


\section{Discussion and recommendations}

Compared to the „traditional" symphony orchestra performances, the previously detailed innovations, novel aspirations renew the value proposition: the orchestras add new elements (e.g., integrating other musical genres and branches of art, creating a multisensory experience, using unusual concert venues, and integrating gamification and interaction) and raise convenience and accessibility. By leveraging digital opportunities, orchestras can redefine the concert experience, reach audiences in a novel and perfectly convenient way, and can overcome the barriers of geographical distance: location is not restricted to concert halls anymore. By adapting to the demographical and social changes of the $21^{\text {st }}$ century, not focusing exclusively on the preservation of classical music, and eliminating the perception that symphony orchestra concerts are not suitable for everyone, these above-mentioned orchestras can address new audiences, including younger people as well.

Besides enriching the value proposition and reaching new customer segments, these orchestras also change significantly other building blocks of their business models (see Table 1 for some examples).

In accordance with Horváth et al. (2018), Csontos \& Szabó (2018), Hortoványi \& Ferincz (2015), Van Alstyne (2016), Gawer \& Cusumano (2014), Eisenmann et al. (2011) and Libert et al. (2014), my research has underpinned the importance of business model innovation and digitalization in the cultural sector as well and has highlighted how virtual reality, platforms, and other software and technologies can contribute to the successful operation of an orchestra by enabling more efficient workflows and creating added value to customers. It is important to emphasize the significance of leadership and management in this process (Morris, 2002): the best music director, the best musicians, and all the money in the world are not enough on their own, the key to success lies in the right leadership. 
Table 1: Business Model Innovation of Symphony Orchestras

\begin{tabular}{|c|c|c|}
\hline Building blocks of BMC & $\begin{array}{l}\text { Orchestras offering } \\
\text { innovative repertoire and } \\
\text { concert experience }\end{array}$ & $\begin{array}{l}\text { Orchestras exploiting the opportunities } \\
\text { offered by digitalization }\end{array}$ \\
\hline Customer segments & $\begin{array}{c}\text { The youth and fans of other } \\
\text { music genres }\end{array}$ & $\begin{array}{l}\text { Children, young people, and those who } \\
\text { would be unable to attend the } \\
\text { performance in person (due to e.g., } \\
\text { geographical distance) }\end{array}$ \\
\hline \multirow[t]{2}{*}{ Value proposition } & $\begin{array}{l}\text { Newness: integrating other } \\
\text { musical genres and branches }\end{array}$ & $\begin{array}{c}\text { Newness: integrating gamification and } \\
\text { adding interaction }\end{array}$ \\
\hline & $\begin{array}{l}\text { of art, creating a } \\
\text { multisensory experience, } \\
\text { using unusual concert venues }\end{array}$ & $\begin{array}{c}\text { Convenience and accessibility: location } \\
\text { is not restricted to concert halls } \\
\text { anymore }\end{array}$ \\
\hline Channels & $\begin{array}{c}\text { The physical space, concert } \\
\text { venues }\end{array}$ & $\begin{array}{l}\text { Platforms, social media, the webpage } \\
\text { of the orchestra }\end{array}$ \\
\hline Customer relationships & $\begin{array}{l}\text { Personal contact with the } \\
\text { audience }\end{array}$ & Automated services, co-creation \\
\hline Revenue structure & Ticket sales & Revenues from streaming \\
\hline Key activities & $\begin{array}{l}\text { Choosing and inviting guest } \\
\text { artists, rehearsals, concerts }\end{array}$ & $\begin{array}{l}\text { Online concert streaming through } \\
\text { platforms, turning the previous } \\
\text { recordings into "virtual experiences" } \\
\text { (video games), using VR for more } \\
\text { effective workflows }\end{array}$ \\
\hline Key resources & $\begin{array}{l}\text { Human and intellectual: the } \\
\text { orchestra, artists and their } \\
\text { knowledge }\end{array}$ & $\begin{array}{c}\text { Technological, human, and intellectual } \\
\text { resources: the platforms and } \\
\text { technologies and employees who can } \\
\text { use them }\end{array}$ \\
\hline Key partners & $\begin{array}{l}\text { Other orchestras, bands, and } \\
\text { representatives of other } \\
\text { branches of arts }\end{array}$ & VR companies, platform owners \\
\hline Cost structure & $\begin{array}{l}\text { Cost of inviting guest artists } \\
\text { (e.g., pop musicians, actors, } \\
\text { dancers, etc.) }\end{array}$ & $\begin{array}{l}\text { Costs of using a platform or software } \\
\text { (e.g., LOLA), recording productions, } \\
\text { and creating video games }\end{array}$ \\
\hline
\end{tabular}

Source: own editing 
Although, business model innovation and digitalization raise some further questions and challenges for orchestras: they have to balance between serving economic goals (e.g., being profitable) and social goals (e.g., creating social value). Furthermore, when innovating the value proposition and creating productions that address the audience in an unusual way, they have to preserve the traditional values of symphony orchestras as well. Digitalization also poses great difficulties: previously, the operation of orchestras relied on live performances, while currently - as a result of the pandemic - they have to focus on the online space. It requires different models and productions: the previously successful performances are not necessarily popular in the virtual space. In order to overcome these barriers and achieve long-term success, orchestras have to continuously experiment, adapt to the changing needs of their customers and handle the changes of the world.

\section{References}

ADO (2021) Australian Discovery Orchestra. https://australiandiscoveryorchestra.com

Agee, J. (2009): Developing qualitative research questions: a reflective process. International Journal of Qualitative Studies in Education, 22(4), pp. 431-447. https://doi.org/10.1080/09518390902736512.

Van Alstyne, M. W., Parker, G. G. \& Choudary, S. P. (2016): Pipelines, Platforms, and the New Rules of Strategy: Scale now trumps differentiation. Hardvard Business Review, 94(April), pp. 54-62. https://doi.org/https://hbr.org/2016/04/pipelines-platforms-andthe-new-rules-of-strategy

Alexander, V. D. (2015): Markets: Artistic and Cultural. In James D. Wright (ed.), International Encyclopedia of the Social \& Behavioral Sciences (pp. 564-568). Amsterdam: Elsevier. https://doi.org/10.1016/B978-0-08-097086-8.10410-6

Association of Hungarian Symphony Orchestras (2020): Zenekaraink on-line aktivitása. ZeneKar, 28(1), pp. 49-51.

Bibu, N., Brancu, L. \& Teohari, G. A. (2018): Managing a Symphony Orchestra in Times of Change: Behind the Curtains. Procedia - Social and Behavioral Sciences, 2 38, 507 516. https://doi.org/10.1016/j.sbspro.2018.04.030

Constantinou, C. S. - Georgiou, M. - Perdikogianni, M. (2017): A comparative method for themes saturation (CoMeTS) in qualitative interviews. Qualitative Research, 17(4), pp. $571-588$.

Corton, M. (2020): Looking for monetized platforms in a pandemic - Part 2. https://www.synchtank.com/blog/looking-to-monetized-music-platforms-in-a-pandemicpart-2/

Csontos, R. S. \& Szabó, Z. R. (2018): A versengés új színterei: platformok stratégiaimenedzsment-megközelítésből. Vezetéstudomány - Budapest Management Review, 49 (9). pp. 57-69. https://doi.org/10.14267/VEZTUD.2018.09.05

Csukás, M. \& Szabó, Z. R. (2019): Platform ambidexterity: fundamental tensions in platform strategies Conferencepaper: EURAM 2019 Conference 
Digital Concert Hall (2019) https://www.digitalconcerthall.com/en/info

Downs, J. B. \& Velamuri, V. K. (2018): Business model innovation in a knowledge revolution:

An evolutionary theory perspective. Managerial and Decision Economics, 39(5), pp. 550562. https://doi.org/10.1002/mde.2926

Drioli, C. Allocchio, C. \& Buso, N. (2013): Networked Performances and Natural Interaction via LOLA: Low Latency High Quality A/V Streaming System. In: Nesi P., Santucci R.

(eds.): Information Technologies for Performing Arts, Media Access, and Entertainment.

ECLAP 2013. Lecture Notes in Computer Science, 7990. pp. 240-250.

https://doi.org/10.1007/978-3-642-40050-6_21

Eisenmann, T., Parker, G., \& Van Alstyne, M. (2011). Platform envelopment. Strategic

Management Journal, 32(12), pp. 1270-1285. https://doi.org/10.1002/smj.935

Figaro (2013): Kihalóban a komolyzene közönsége? [Is dying out the audience of classical music?] http://figaro.reblog.hu/uresen-konganak-az-operahazak

Forbes (2020): The 2020 World's Most Valuable Brands. https://www.forbes.com/the-worldsmost-valuable-brands/\#27af0694119c

Gawer, A. \& Cusumano, M. A. (2014): Industry platforms and ecosystem innovation. Journal of Product Innovation Management, 31(3), pp. 417-433.

https://doi.org/10.1111/jpim.12105

Grasmayer, B. (2017): Four innovations in classical music https://www.musicxtechxfuture.com/2017/05/22/four-innovations-in-classical-music/

Horváth, D., Móricz, P. \& Szabó Z. R. (2018): Üzletimodell-innováció [Business Model Innovation]. Vezetéstudomány, 49(6), pp. 2-12. https://doi.org/10.14267/VEZTUD.2018.06.01

Hortoványi, L. (2012): Entrepreneurial Management. Budapest: AULA

Hortoványi, L. \& Ferincz, A. (2015): The impact of ICT on learning on-the-job. The Learning Organization 22(1), pp. 2-13. https://doi.org/10.1108/TLO-06-2014-0032

Hunt, N. (2019): How TSO and its new music director plan to attract younger audiences and revitalize classical music in Canada. August 31. CBC News.

https://www.cbc.ca/news/entertainment/tso-gustavo-gimeno-revitalizing-classical-music1.5253601

Libert, B., Wind, Y. \& Beck, M. (2014). What Airbnb, Uber, and Alibaba Have in Common. https://hbr.org/2014/11/what-airbnb-uber-and-alibaba-have-in-common

LOLA (2021) https://lola.conts.it/

Markides, C. (1997): Strategic Innovation. Sloan Management Review, 38(5), pp.9-23.

Mészáros, T. (2020): A stratégiaalkotás változásának mozgatórugói, fejlődési trendjei a XXI. században. Köz-gazdaság, 15(1), pp. 30-42. https:/doi.org/10.14267/RETP2020.01.04

Morris, T. W. (2002): Symphony Orchestra Boards and Board Leadership. Harmony: Forum of the Symphony Orchestra Institute, 14, pp. 47-52.

Naderifar, M., Goli, H. \& Ghaljaie, F. (2017): Snowball Sampling: A Purposeful Method of Sampling in Qualitative Research. Strides in Development of Medical Education, 14(3), pp. 1-6. https://doi.org/10.5812/sdme.67670 
Osterwalder, A. \& Pigneur, Y. (2010) Business Model Generation: A Handbook for Visionaries, Game Changers, and Challengers. Chichster: Wiley

Porter M. E. (2001): Strategy and the Internet. Harvard Business Review, 79(3), 62-78. Retrieved from https://www.gospi.fr/IMG/pdf/strategy-and-the-internetporter-hbr2001.pdf

Radbourne, J. \& Arthurs, A. (2007): Adapting musicology for commercial outcomes. In Radbourne, J. \& Arthurs, A. (ed.): Proceedings Valencia Spain - 9th International Conference on Arts and Cultural Management (AIMAC 2007) CD A1-4, pp. 1-13. Valencia, Spain.

Szabó, Z. R., Horváth, D. \& Hortoványi, L. (2019): Hálózati tanulás az ipar 4.0 korában. Közgazdasági szemle, 66(1), pp. 72-94. http://dx.doi.org/10.18414/KSZ .2019.1.72

Teivainen, A. (2020): Finnish VR pioneers put heads together to re-imagine performing arts. https://www.goodnewsfinland.com/finnish-vr-pioneers-put-heads-together-to-re-imagineperforming-arts /

Váradi, J. (2010): Hogyan neveljünk értô közönséget a komolyzenének? [How to educate an audience to acquire a taste for classical music?] PhD Dissertation, University of Jyväskylä.

Weerawardena, J., Salunkeb, S., Haighc, N., \& Mort, G. S. (2019): Business model innovation in social purpose organizations: Conceptualizing dual social-economic value creation. Journal of Business Research, in press. https://doi.org/10.1016/j.jbusres.2019.10.016

Zott, C., Amit, R. \& Massa, L. (2011): The business model: recent development and future research. Journal of Management, 37(4), pp. 1019-1042.

https://doi.org/10.1177/0149206311406265 